\title{
An Integrated Assessment of Energy Crops Production in Taiwan
}

\author{
Ya-Ling Lai, Yu-Jay Chang, Shu-Yi Liao* \\ Department of Applied Economics, National Chung Hsing University, Taiwan \\ Email:a670040@wra.gov.tw, deliacyc@hotmail.com, *sliao@nchu.edu.tw
}

How to cite this paper: Lai, Y.-L., Chang, Y.-J. and Liao, S.-Y. (2019) An Integrated Assessment of Energy Crops Production in Taiwan. Modern Economy, 10, 1430-1445. https://doi.org/10.4236/me.2019.105096

Received: March 29, 2019

Accepted: May 24, 2019

Published: May 27, 2019

Copyright $\odot 2019$ by author(s) and Scientific Research Publishing Inc. This work is licensed under the Creative Commons Attribution International License (CC BY 4.0).

http://creativecommons.org/licenses/by/4.0/

\begin{abstract}
For countries with scarce fossil fuel resources and limited cropland, how would energy crops production increase energy security and affect land use and farmer's income? To address such questions, we develop an integrated assessment model to evaluate land use changes and economic impacts of energy crop policy in Taiwan. The model consists of several submodels linked together interactively, representing different components of the integrated agricultural-energy-environmental-economic system. Five major findings and policy implications can be drawn from our study: 1) There is lack of economic incentives for farmers to produce energy crops using set-aside croplands without government subsidies. The required subsidies for energy crops production will be $50 \%$ to $120 \%$ higher than the original subsidies for set-aside croplands. 2) There is very little economic incentive for farmers to switch to energy crop production from existing crop production even with government subsidies. Therefore, the impacts on the supply and demand of existing agricultural crops are very minor. 3) Among four soil grades, more than half of the total energy crop output comes from Grade II soil, which is mostly located in the West Tainan County. This implies that energy crop mills and refining plants should be located in the West Tainan County to minimize the transportation costs. 4) The results from general equilibrium modeling show that the Miscellaneous Crops sector will incur the largest increase in output due to energy crop production. In the case of sunflower production, the ratio of total output increase to total government subsidies is about 1.12, which is the only energy crop with benefit-cost ration greater than 1.0. This implies that sunflower is the most economical feasible choice among three energy crops. 5) In the case of sunflower production, the total employment and average monthly wage rates in the Agricultural Sector will increase by $6.7 \%$ and $71.7 \%$, respectively. This indicates that sunflower production will have significant positive economic impacts on the employment and income of farmers in Tainan County.
\end{abstract}




\section{Keywords}

Energy Crop, Integrated Assessment, Land Use Change, Economic Impacts

\section{Introduction}

During the past few decades, there has been increasing attention given to the issue of global climate change and its consequences for natural systems and human society. Several options could be used to reduce greenhouse gas (GHG) emission to mitigate its impacts on global climate. For example, increasing biomass energy production, changing agricultural land use, carbon sequestration by forests, and other economic policy instruments, including carbon tax and carbon permit trading, all have potentials to reduce the atmospheric concentration of GHG [1] [2] [3]. In addition to reducing overall fossil fuel demand and improving energy use efficiency, all policy instruments provide incentives to shift energy consumption from high-carbon fuels to low or non-carbon fuels in the short run and mitigate the impacts of global climate change on natural systems and human society in the long run.

Sustained high crude oil prices since the early 21 century has once again become a major concern to the world, especially countries with scarce energy resources. Since crude oil imports will continue to remain a dominant part of energy supply in Taiwan, the need for a robust domestic renewable energy industry to increase energy security has never been greater. For countries with scarce fossil fuel resources and limited cropland, how would energy crops production increase energy security and affect land use and farmer's income? To address such questions, we develop an integrated assessment model to simulate the land use changes and economic impacts of energy crop policy in Taiwan. The model consists of several submodels linked together interactively, representing different components of the integrated agricultural-energy-environmental-economic (IAEEE) system.

Most of the integrated economy-climate studies are aggregated models which specify economic behavior from a top-down perspective. There are many top-down models for individual countries or regions that have detail production technologies for the agriculture sector and that are able to investigate the impacts of shifting agricultural production on the whole economy [4] [5] [6]. However, what lacks is a detail description of land use types, land productivity and rent, agricultural products, and energy sectors and specific technologies from a bottom-up perspective to fully investigate the dynamic interactions between land use change, agriculture production, energy demand, and GHG emissions in the economy [7] [8]. Therefore, our approach is to make the IAEEE assessment model a full integration of a computable general equilibrium model of the economy with detail agriculture production, energy input, and land use modeling components to analyze the underlying dynamics of economic and land use and cover changes over time in relation to energy 
crop production.

The empirical results show five major findings: First, there will be lack of economic incentives for farmers to produce energy crops using set-aside croplands without government subsidies. The required subsidies for energy crops production will be $50 \%$ to $120 \%$ higher than the original subsidies for set-aside croplands. Second, there is very little economic incentive for farmers to switch to energy crop production from existing crop production even with government subsidies. Therefore, the impacts on the supply and demand of existing agricultural crops are very minor. Third, based on the geographic distribution of cropland land and soil grades, West Tainan County accounts for more than two-third of total energy crop output in Tainan County. This implies that energy crop mills and refining plants should be located in the West Tainan County to minimize the transportation costs.

Fourth, the results from general equilibrium modeling show that the Miscellaneous Crops sector, which includes energy crops, will incur the largest increase in output due to energy crop production. It accounts for more than $50 \%$ of total output increase (51.6 million NT\$) in Tainan County. In the case of sunflower production, the ratio of total output increase to total government subsidies is about $1.12(=51.6 / 46.0)$, which is the only energy crop with benefit-cost ration greater than 1.0. This implies that sunflower will be the most economic feasible choice among three energy crops. Finally, in the case of sunflower production, the total employment and average monthly wage rates in the Agricultural Sector will increase by $6.7 \%$ and $71.7 \%$, respectively. This indicates that sunflower production will have significant positive economic impacts on the employment and income of farmers in Tainan County.

The remainder of this paper is organized as follows: the next section includes a brief discussion of previous literature in this field of research. Section 3 describes the theoretical model and integrating modeling approach. Section 4 shows the empirical results for three different energy crop production simulations. The final section provides policy implications for energy crop production in Taiwan.

\section{Literature Review}

Recent rapid growing demand in Europe and North America for biofuels from energy crops is one of the responses to stringent environmental policies to reduce GHG emissions and sustained high oil prices. Biofuels production from energy crops not only can lessen the negative impacts of global climate change and soaring crude oil prices on the economy, but also can increase energy security, improve farmland use efficiency, and increase farmer income [9] [10] [11] [12] [13]. However, with limited available cropland supply, large-scale energy crops production might increase pressure on the current productive cropland and might induce a substantial increase of agriculture product prices [14] [15] [16]. One of the possible solutions is to plant energy crops using currently 
set-aside cropland, which can deliver large quantity of energy at low GHG emissions levels without increasing pressure on the current productive cropland.

Several studies have quantified the potential biofuels supply from energy crops on the global and national scales. For example, Berndes et al. [17] estimate the global potential biofuels supply from biomass and agricultural and forestry residuals ranges from 311 to $706 \mathrm{EJ} /$ year in the business as usual and GHG emissions mitigation scenario, respectively. Gurgel et al. [13] estimate by the year of 2100 global biofuels production could reach 221 to $267 \mathrm{EJ} /$ year in a business as usual scenario, and 319 to $368 \mathrm{EJ}$ under a global effort to reduce GHG emissions scenario. On the national scale, Walsh et al. 9] estimate that energy crops could supply approximately $1.6 \mathrm{EJ} /$ year of primary energy in the US if high productivity management practices are permitted on Conservation Reserve Program lands. According to Yamamoto et al. [10], the potential biofuels supply from energy crops produced on unused arable land is about 0.24 EJ/year in Japan, which accounts about $1.0 \%$ of the total primary energy supply.

Most of the global studies are aggregated models which specify economic behavior from a top-down perspective. There are many top-down models for individual countries that have detailed production technologies for the energy sector and that are able to investigate the impacts of shifting energy production [18] [19] [20]. However, what lacks is a detailed description of land use classes, agricultural products, and energy sectors and specific technologies from a bottom-up perspective to fully investigate the dynamic interactions between land use change, agriculture production, energy supply, and GHG emission mitigation in the economy.

\section{Theory and Approach}

\subsection{Theoretical Model}

The work of the Intergovernmental Panel on Climate Change (IPCC) has, over the past few decades, encouraged use of integrated assessment processes and models to understand socio-economic and environment aspects of bioenergy systems. Many of the models focus on one kind of process or sector-such as models relating agricultural productivity, energy production technology, or water resources to energy crop production [13] [17]. Our approach differs from previous integrated models by focusing on interactive relationship between agricultural production, energy supply, environmental impacts, and economic growth. The basic model goal is to investigate the potential impacts of energy crop production in Taiwan with a high degree of geographic resolution of land use classes.

To estimate the potential impacts of energy crop production in Taiwan, our model consists of two interrelated systems: human-socioeconomic system and human-environmental system (Figure 1). The human-socioeconomic system is used to simulate socioeconomic activities and population growth in the study region and to compute GHG emissions. The major submodel included in the 


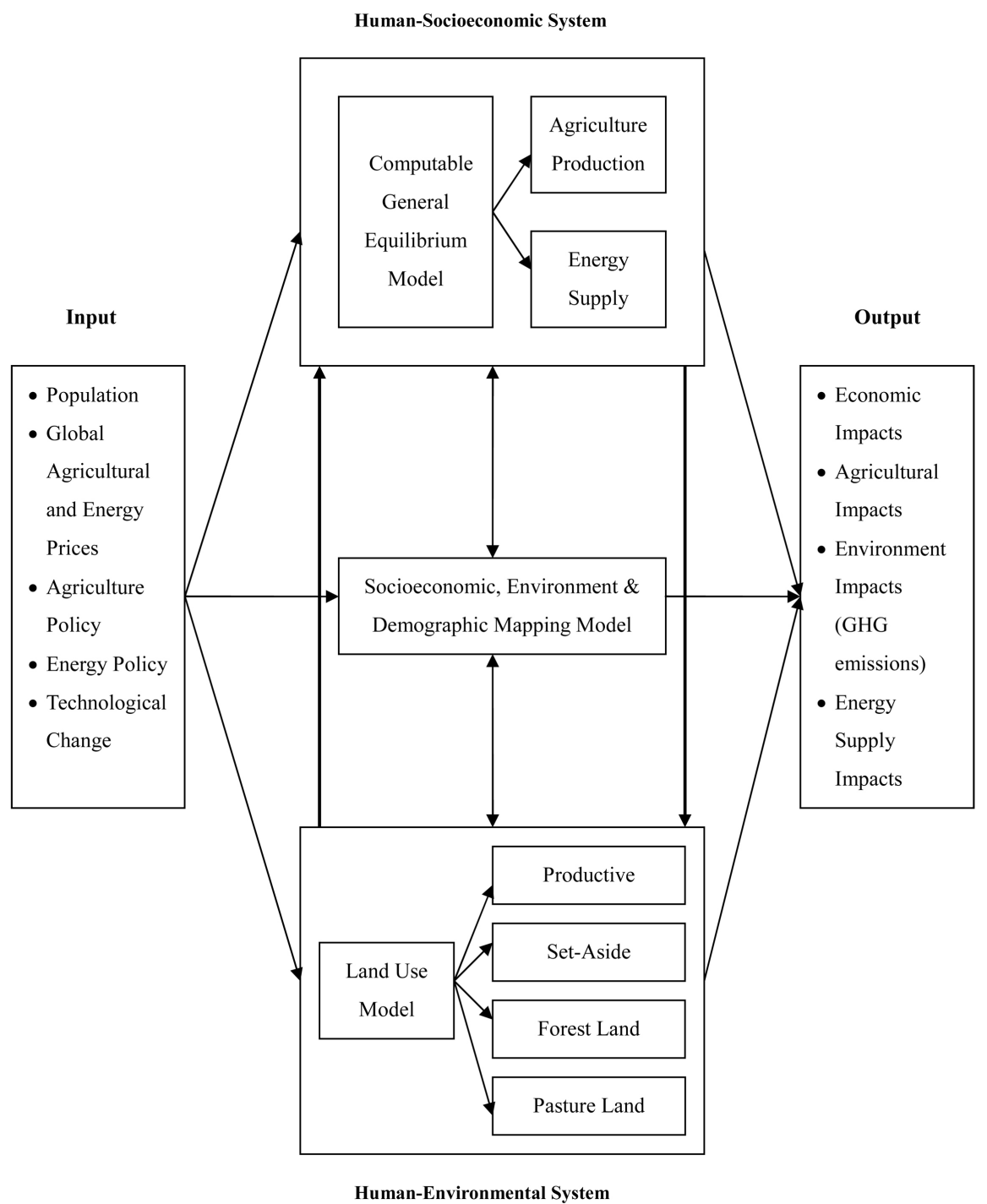

Figure 1. IAEEE modeling framework.

system is a computable general equilibrium (CGE) model and a land use (LAND) model with detailed agriculture and energy sectors. The human-environmental system is used to simulate the change in cropland use based on socioeconomic factors. The major submodelis an agricultural sector model with detailed regional productive cropland use and set aside cropland data. The socioeconomic, environmental, and demographic mapping model is designed to map employment, population, and land use at regional level consistent with the employment and population simulation in the CGE model and cropland use simulation in the agricultural sector model.

\subsection{Scope and Data Source}

The Taiwan agricultural sector model consists of 60 traditional crops, 5 floral crops, 7 livestock species, 3 types of forests (conifers, hardwoods, and bamboo) and 27 secondary commodities. In the year 2004, the total value of primary 
agricultural commodities accounted for more than 85 percent of Taiwan's total agricultural product value. Sub-regional production activities are specified in the model for each commodity. Crop and livestock mixes activities and constraints are also specified at the sub-regional level, while the input markets for four different land classes and farm labor are specified at the regional level.

Our empirical model was validated based on the comparison between the equilibrium solution and actual statistics. The year 2004 was chosen as the baseline to construct the database because preliminary energy crop plantation experiment was conducted in the year 2005. We used both the total production and prices as the basis to validate our model. The data sources are mainly from published government statistics and research reports, which include Taiwan Agricultural Yearbook, Production Cost and Income of Farm Products Statistics, Commodity Price Statistics Monthly, Taiwan Agricultural Prices and Costs Monthly, Taiwan Area Agricultural Products Wholesale Market Yearbook, Trade Statistics of the Inspectorate-General of Customs, and Forestry Statistics of Taiwan. Demand elasticities of agricultural products were estimated through a comprehensive survey of various sources.

The land use model is based on a Tainan County geographic information system $(1 / 25,000)$, which is one of the major crop producing counties in Taiwan. It includes five major database: 1) natural environment database which includes geology, soil, and hydrology data; 2) natural resource and ecological database which includes agriculture and forestry data; 3) social and economic database which includes population, income, regional economy, agriculture, industry statistics data; 4) rural and urban planning database which includes land use and zoning information; 5) transportation network database which includes highway, railway, and transportation data.

The coupling of IAEEE model and LAND model is established by exchanging crop prices, as determined by the CGE model, with land allocation changes, as calculated by the LAND model. In the coupled framework the energy crop allocation in LAND model is determined at county level. Aggregated to the national resolution and then the percentage change of allocated area shares is fed into the CGE model. The resulting price changes are calculated by the CGE model and used to update prices and yields in the LAND model. The coupling algorithm can be divided into two main procedures. The first step is a convergence test. The convergence test aims to investigate the convergence of the coupled system and, in case a divergence is detected, to adjust accordingly the key parameters (e.g., elasticities of substitution) in order to reach convergence. The second step is the baseline simulation which transfers both CGE model and LAND model into a consistent benchmark of the future. The values of key economic variables shaping the base-year equilibrium in the CGE model will be updated according to projected future changes. This step is done in the CGE model with endogenous land allocation. The resulting changes thus imply land allocation changes comparing with the base-year equilibrium. 


\subsection{Simulation Scenario}

Taiwan imported about $98 \%$ of total primary energy use in 2004. Therefore, if the set-aside cropland could be utilized to plant energy crops, the amount of energy imports could be reduced eventually. In 2004, total agricultural cropland was 0.83 million hectares, with 0.28 million hectares of set-aside cropland. Set-aside area has increased substantially mainly due to falling prices and incomes caused by Taiwan's entry into the WTO and the consequent importation of low priced rice and other agricultural commodities. Since crude oil imports will continue to remain a dominant part of energy supply in Taiwan, utilizing set-aside cropland to plant energy crops is considered as one of the major policy instruments to increase energy security and reduce GHG emissions. Therefore, our simulation scenarios are based on existing agricultural energy crop policy and biofuels energy policy as well as potential policy changes in the future.

\section{Empirical Results}

Based on a small-scale pilot experiment of energy crop production, three different kinds of energy crops, including soybean, oilseed rape, and sunflower, were chosen to simulate the land use changes and economic impacts of energy crop production for the entire Tainan County. According to the results of the small-scale pilot experiment, Table 1 shows that the gross profits of soybean, oilseed rape, and sunflower production are $-46.2,-54.8$, and -22.3 thousand NT\$ per hectare (ha), respectively. With the government subsidy, the net profits of these three energy crops increase to 13.8, 5.2, and 37.7 thousand NT\$ per hectare, respectively. This indicates that there will be lack of economic incentives for the farmers to planting energy crops even with extra production inputs subsidies (15 thousand NT\$ per hectare) compared with initial set-aside cropland subsidies (45 thousand NT\$ per hectare).

Table 2 shows the average yields and biodiesel output of energy crops based

Table 1. Energy crop production costs and revenues.

\begin{tabular}{|c|c|c|c|c|c|c|c|c|}
\hline & \multirow{2}{*}{$\begin{array}{c}\text { Production } \\
\text { Cost } \\
\text { (NT\$/ha) }\end{array}$} & \multirow{2}{*}{$\begin{array}{l}\text { Average } \\
\text { Output } \\
\text { (kg/ha) }\end{array}$} & \multirow{2}{*}{$\begin{array}{c}\text { Sales } \\
\text { Revenue } \\
\text { (NT\$/ha) }\end{array}$} & \multirow{2}{*}{$\begin{array}{c}\text { Gross } \\
\text { Profit } \\
\text { (NT\$/ha) }\end{array}$} & \multicolumn{2}{|c|}{$\begin{array}{l}\text { Subsidy } \\
\text { (NT\$/ha) }\end{array}$} & \multicolumn{2}{|c|}{$\begin{array}{l}\text { Net Profit } \\
\text { (NT\$/ha) }\end{array}$} \\
\hline & & & & & Set-Aside & Inputs & $\begin{array}{l}\text { Before } \\
\text { Subsidy }\end{array}$ & $\begin{array}{c}\text { After } \\
\text { Subsidy }\end{array}$ \\
\hline Soybean & 59,777 & 1089 & 13,613 & $-46,165$ & 45,000 & 15,000 & $-46,165$ & 13,836 \\
\hline Oilseed Rape & 65,690 & 808 & 10,908 & $-54,782$ & 45,000 & 15,000 & $-54,782$ & 5218 \\
\hline Sunflower & 46,565 & 1012 & 24,288 & $-22,277$ & 45,000 & 15,000 & $-22,277$ & 37,723 \\
\hline
\end{tabular}

Table 2. Average energy crop yield and biodiesel output.

\begin{tabular}{cccc}
\hline & Energy Crop (kg/ha) & Conversion Factor (\%) & Biodiesel (liter/ha) \\
\hline Soybean & 1089 & 15.6 & 169.8 \\
Oilseed Rape & 808 & 36.4 & 294.1 \\
Sunflower & 1012 & 36.3 & 367.3 \\
\hline
\end{tabular}


on the results of the small-scale pilot experiment. Among three energy crops, sunflower has the highest biodiesel output per hectare because of relatively higher yields per hectare and biodiesel conversion factor compared with soybean and oilseed rape. A summary of crop yields and biodiesel output for all municipals in Tainan County is shown in Table 3. Figures 2-5 show the geographic

Table 3. Total energy crop yield and biodiesel output in Tainan county.

\begin{tabular}{|c|c|c|c|c|c|c|c|}
\hline \multirow[b]{2}{*}{$\begin{array}{l}\text { Municipal } \\
\text { Code }\end{array}$} & \multirow[b]{2}{*}{$\begin{array}{c}\text { Cropland- } \\
\text { Area } \\
\text { (ha) }\end{array}$} & \multicolumn{2}{|c|}{ Soybean } & \multicolumn{2}{|c|}{ Oilseed Rape } & \multicolumn{2}{|c|}{ Sunflower } \\
\hline & & $\begin{array}{l}\text { Crop } \\
\text { Yield } \\
(\mathrm{kg})\end{array}$ & $\begin{array}{c}\text { Biodiesel } \\
\text { Output } \\
\text { (liter) }\end{array}$ & $\begin{array}{l}\text { Crop } \\
\text { Yield } \\
(\mathrm{kg})\end{array}$ & $\begin{array}{c}\text { Biodiesel } \\
\text { Output } \\
\text { (liter) }\end{array}$ & $\begin{array}{l}\text { Crop } \\
\text { Yield } \\
(\mathrm{kg})\end{array}$ & $\begin{array}{c}\text { Biodiesel } \\
\text { Output } \\
\text { (liter) }\end{array}$ \\
\hline M1 & 16.12 & 17,564 & 2740 & 13,032 & 4744 & 16,323 & 5925 \\
\hline M2 & 25.95 & 28,266 & 4409 & 20,972 & 7634 & 26,267 & 9535 \\
\hline M3 & 20.22 & 22,027 & 3436 & 16,343 & 5949 & 20,470 & 7430 \\
\hline M4 & 7.60 & 8282 & 1292 & 6145 & 2237 & 7696 & 2794 \\
\hline M5 & 15.24 & 16,602 & 2590 & 12,318 & 4484 & 15,428 & 5600 \\
\hline M6 & 20.20 & 22,002 & 3432 & 16,325 & 5942 & 20,447 & 7422 \\
\hline M7 & 17.37 & 18,926 & 2953 & 14,043 & 5112 & 17,588 & 6385 \\
\hline M8 & 16.13 & 17,575 & 2742 & 13,040 & 4747 & 16,332 & 5929 \\
\hline M9 & 18.76 & 20,434 & 3188 & 15,161 & 5519 & 18,989 & 6893 \\
\hline M10 & 68.50 & 74,597 & 11,637 & 55,349 & 20,147 & 69,323 & 25,164 \\
\hline M11 & 13.25 & 14,431 & 2251 & 10,707 & 3898 & 13,411 & 4868 \\
\hline M12 & 62.00 & 67,519 & 10,533 & 50,096 & 18,235 & 62,745 & 22,776 \\
\hline M13 & 187.79 & 204,507 & 31,903 & 151,737 & 55,232 & 190,047 & 68,987 \\
\hline M14 & 9.99 & 10,882 & 1698 & 8074 & 2939 & 10,113 & 3671 \\
\hline M15 & 7.25 & 7902 & 1233 & 5863 & 2134 & 7344 & 2666 \\
\hline M16 & 3.64 & 3971 & 619 & 2946 & 1073 & 3690 & 1340 \\
\hline M17 & 33.71 & 36,718 & 5728 & 27,244 & 9917 & 34,122 & 12,386 \\
\hline M18 & 17.84 & 19,430 & 3031 & 14,417 & 5248 & 18,057 & 6555 \\
\hline M19 & 4.58 & 4991 & 779 & 3703 & 1348 & 4638 & 1684 \\
\hline M20 & 11.89 & 12,950 & 2020 & 9608 & 3497 & 12,034 & 4368 \\
\hline M21 & 17.34 & 18,890 & 2947 & 14,015 & 5102 & 17,554 & 6372 \\
\hline M22 & 28.57 & 31,121 & 4855 & 23,091 & 8405 & 28,921 & 10,498 \\
\hline M23 & 0.31 & 347 & 54 & 258 & 94 & 323 & 117 \\
\hline M24 & 11.47 & 12,498 & 1950 & 9273 & 3375 & 11,614 & 4216 \\
\hline M25 & 13.58 & 14,799 & 2309 & 10,980 & 3997 & 13,752 & 4992 \\
\hline M26 & 34.79 & 37,886 & 5910 & 28,110 & 10,232 & 35,207 & 12,780 \\
\hline Total & 684.22 & 745,119 & 116,239 & 552,853 & 201,238 & 692,434 & 251,354 \\
\hline
\end{tabular}




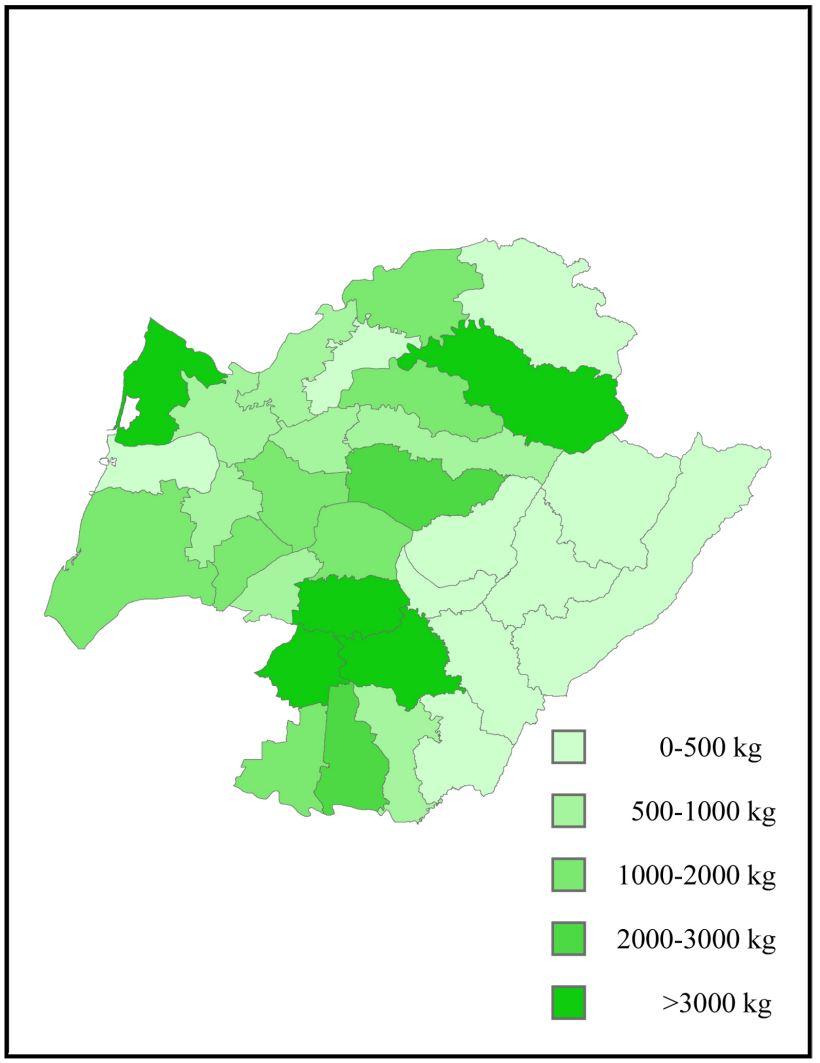

Figure 2. Geographic distribution of grade I soil yield.

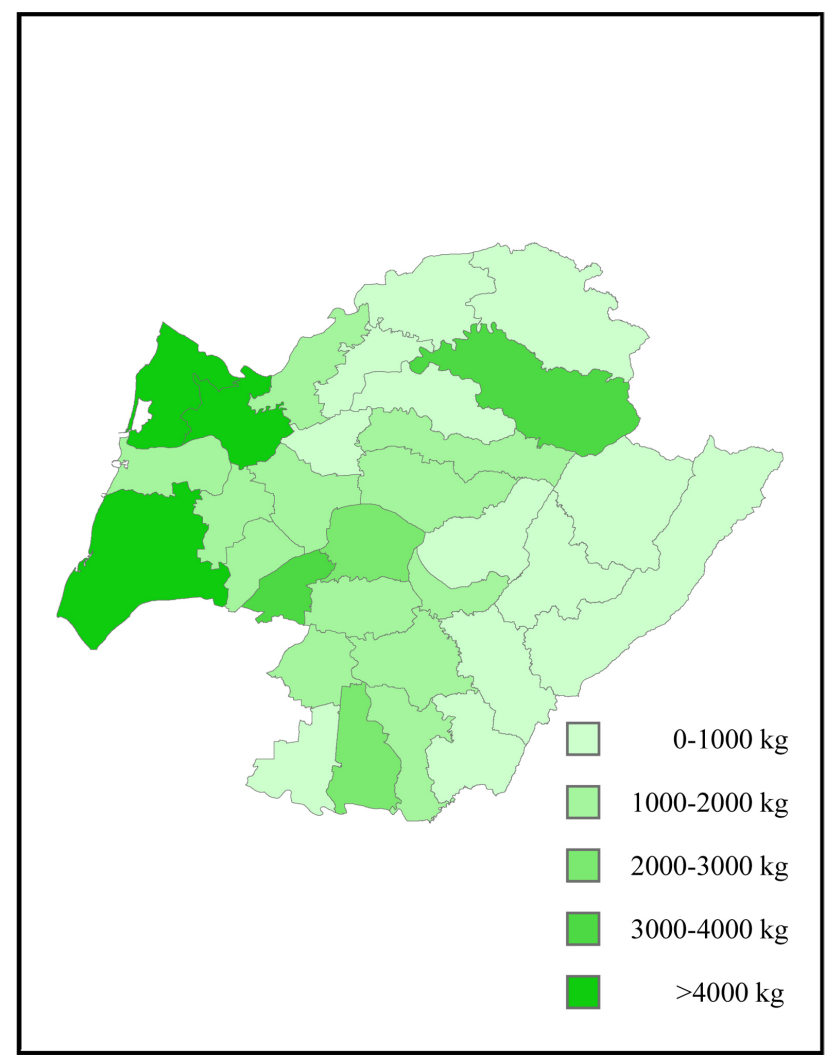

Figure 3. Geographic distribution of grade II soil yield. 


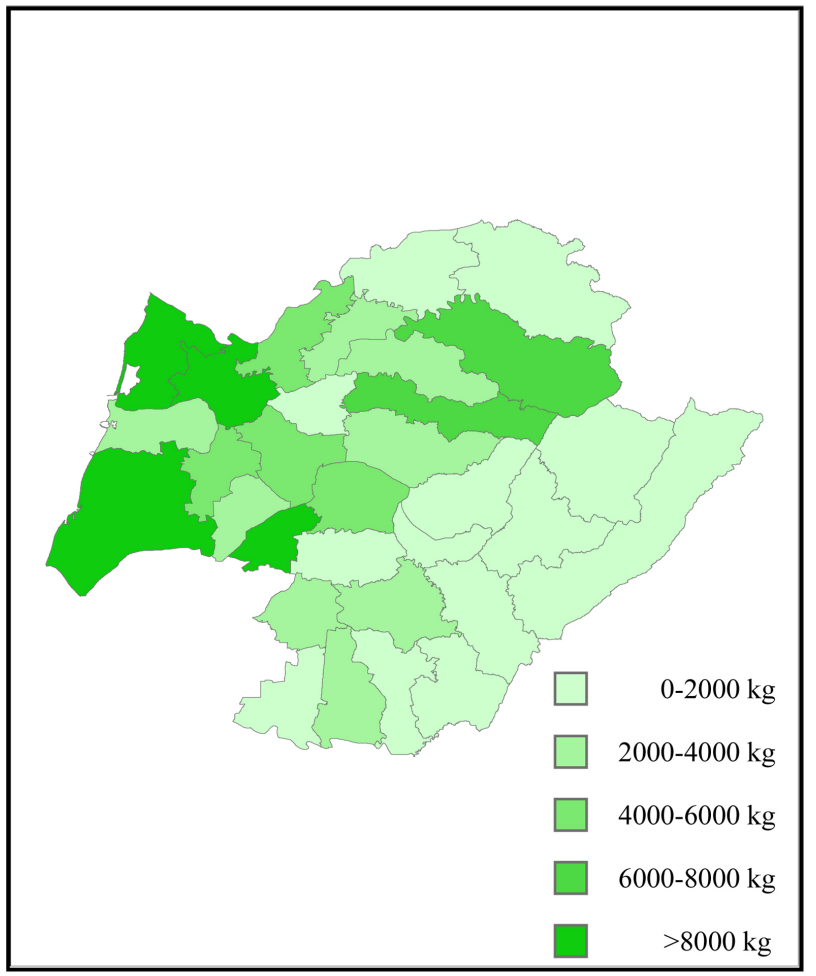

Figure 4. Geographic distribution of grade III soil yield.

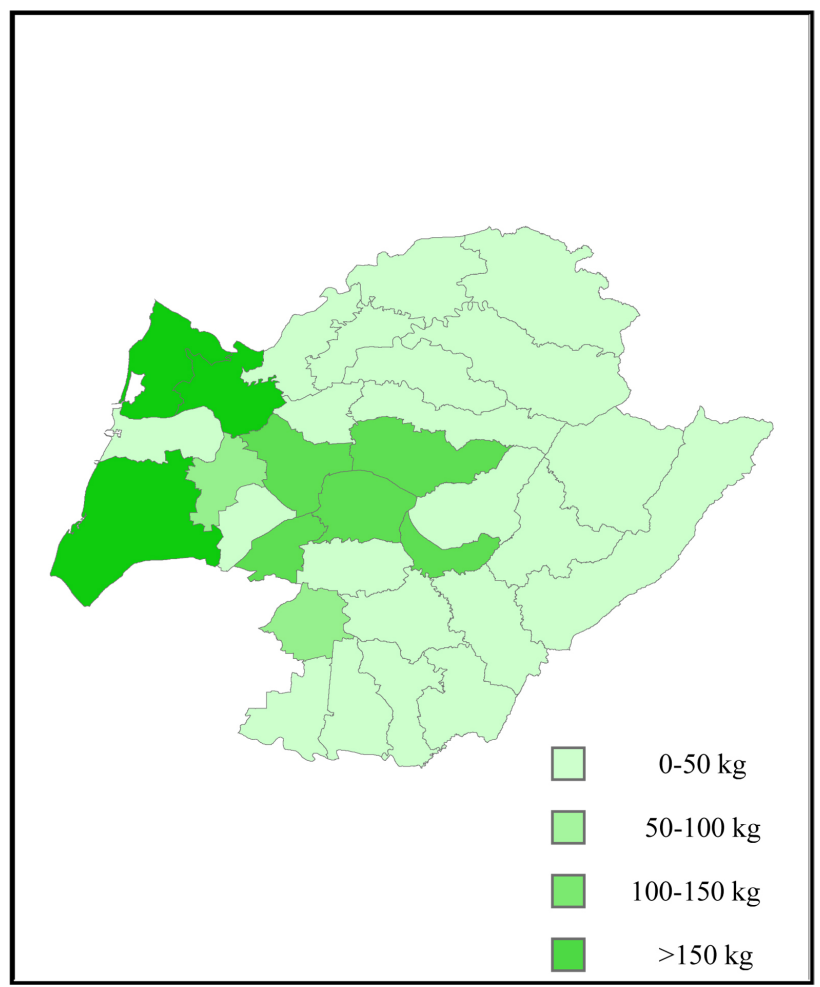

Figure 5. Geographic distribution of grade IV soil yield.

distribution of sunflower yields for four different grades of soil. The areas of set-aside cropland are different for each municipal. Each unit of set-aside crop- 
land is furthered categorized into four different grades of soil. Therefore, each municipal has its own unique geographic distribution of different grades set-aside cropland. For example, Figure 2 shows the sunflower yields of Grade I set-aside cropland in each municipal. Municipals with high sunflower yields are mainly because they have larger areas of Grade I set-aside cropland compared with others. Therefore, crop yields for different grades of soil in each municipal are directly related to their areas of different grades set-aside cropland. According to Figures 2-5, municipals with relatively high crop yields are concentrated in the West Tainan County. For example, Bay-Mum Municipal (M13), which is located at the southwest of Tainan County, accounts for more than one quarter of total crop yields and biodiesel output. In the case of sunflower (see Table 4), more than $90 \%$ of total crop yields are from Grade II and III soil, which are located mostly in the West of Tainan County.

The extra government subsidies needed to make farmers willing to plant energy crops in addition to current set-aside cropland subsidies are shown in Table 5. Among three energy crops, sunflower requires the lowest additional subsidies of 15.2 million NT\$, which is about $50 \%$ of initial set-aside cropland subsidies (30.8 million NT\$). As for the other two energy crops, the required additional subsidies are more than the initial set-aside cropland subsidies. This implies that it will be economically infeasible to produce biodiesel from soybean, oilseed rape, and sunflower without considering the general equilibrium economic impacts of energy crop production on the economy of Tainan County.

Table 6 represents the general economic impacts of energy crop production on the economy of Taiwan County by sector. Among three energy crops, sunflower has the largest total output increases of 51.6 million NT\$. In terms of sectoral output increase, the Miscellaneous Crops sector will incur a significant increase in output (15.7 million NT\$) due to energy crop production. In the case of sunflower production, the ratio of total output increase to total government

Table 4. Energy crop yield by soil grade in Tainan county (kg).

\begin{tabular}{|c|c|c|c|c|c|}
\hline & I & II & III & IV & Total \\
\hline Soybean & 26,033 & 582,725 & 49,593 & 86,768 & 745,119 \\
\hline Oilseed Rape & 208,543 & 190,183 & 149,772 & 4356 & 552,853 \\
\hline Sunflower & 34,154 & 466,851 & 187,006 & 4424 & 692,434 \\
\hline
\end{tabular}

Table 5. Energy crop production subsidies for set-aside cropland in Tainan county.

\begin{tabular}{ccccccccc}
\hline & \multicolumn{3}{c}{ Without Energy Crop Planting } & \multicolumn{5}{c}{ With Energy Crop Planting } \\
\cline { 2 - 9 } & $\begin{array}{c}\text { Set-Aside } \\
\text { Area (ha) }\end{array}$ & $\begin{array}{c}\text { Subsidy } \\
(\mathrm{NT} / \mathrm{ha})\end{array}$ & $\begin{array}{c}\text { Total } \\
\text { Subsidy } \\
(\mathrm{NT} \$)\end{array}$ & $\begin{array}{c}\text { Breakeven } \\
\text { Price } \\
(\mathrm{NT} / \mathrm{kg})\end{array}$ & $\begin{array}{c}\text { Wholesale } \\
\text { Price } \\
(\mathrm{NT} / \mathrm{kg})\end{array}$ & $\begin{array}{c}\text { Average } \\
\text { Yield } \\
(\mathrm{kg} / \mathrm{ha})\end{array}$ & $\begin{array}{c}\text { Additional } \\
\text { Subsidy } \\
(\mathrm{NT} \$)\end{array}$ & $\begin{array}{c}\text { Total } \\
\text { Subsidy } \\
(\mathrm{NT} \$)\end{array}$ \\
\hline Soybean & 684.22 & 45,000 & $30,790,058$ & 96.2 & 12.5 & 1089 & $31,586,836$ & $62,376,894$ \\
Oilseed Rape & 684.22 & 45,000 & $30,790,058$ & 136.9 & 13.5 & 808 & $37,483,132$ & $68,273,190$ \\
Sunflower & 684.22 & 45,000 & $30,790,058$ & 90.4 & 24.0 & 1012 & $15,242,447$ & $46,032,505$ \\
\hline
\end{tabular}


Table 6. Economic impacts of energy crop production on Tainan county by sector (output increase in NT\$).

\begin{tabular}{|c|c|c|c|}
\hline Sector & Soybean & Oilseed Rape & Sunflower \\
\hline 1) Rice & 4949 & 4274 & 9038 \\
\hline 2) Miscellaneous Crops & $15,667,386$ & $13,528,286$ & $28,608,684$ \\
\hline 3) Sugarcane & 2752 & 2376 & 5024 \\
\hline 4) All Other Grains & 5733 & 4950 & 10,470 \\
\hline 5) Fruit and Tree Nut & 44,887 & 38,758 & 81,965 \\
\hline 6) Vegetable and Melon & 778 & 672 & 1421 \\
\hline 7) Greenhouse and Nursery & 208,055 & 179,650 & 379,910 \\
\hline 8) Support Activities for Crop Production & $4,224,103$ & $3,647,378$ & $7,713,223$ \\
\hline 9) Animal Production & 136,787 & 118,111 & 249,773 \\
\hline 10) Forestry and Logging & 7883 & 6806 & 14,394 \\
\hline 11) Fishery & 1670 & 1442 & 3049 \\
\hline 12) Mining & 701,838 & 606,014 & $1,281,558$ \\
\hline 13) Food Manufacturing & 89,177 & 77,002 & 162,838 \\
\hline 14) Beverage and Tobacco Product & 1876 & 1620 & 3427 \\
\hline 15) Textile Mills & 21,876 & 18890 & 39,948 \\
\hline 16) Textile, Apparel, Leather Product & 3184 & 2750 & 5815 \\
\hline 17) Wood Product Manufacturing & 39,753 & 34,326 & 72,590 \\
\hline 18) Paper and Printing & 163,398 & 141,088 & 298,365 \\
\hline 19) Chemical Manufacturing & 659,541 & 569,492 & $1,204,323$ \\
\hline 20) Artificial Synthetic Fibers & 7992 & 6901 & 14,594 \\
\hline 21) Plastics and Rubber Products & 284,818 & 245,931 & 520,079 \\
\hline 22) Other Chemical products & $1,210,436$ & $1,045,172$ & $2,210,258$ \\
\hline 23) Petroleum Products & 775,739 & 669,826 & $1,416,502$ \\
\hline 24) Coal Products & 19,771 & 17,072 & 36,103 \\
\hline 25) Nonmetallic Mineral Product & 35,900 & 30,998 & 65,553 \\
\hline 26) Iron and Steel & 244,557 & 211,167 & 446,561 \\
\hline 27) Other Primary Metal & 98,420 & 84,983 & 179,716 \\
\hline 28) Fabricated Metal Product & 74,399 & 64,242 & 135,855 \\
\hline 29) Machinery & 259,642 & 224,192 & 474,108 \\
\hline 30) Computer and Electronic Product & 25,600 & 22,105 & 46,747 \\
\hline 31) Electrical Equipment & 58,002 & 50,082 & 105,911 \\
\hline 32) Appliance and Component & 59,840 & 51,670 & 109,269 \\
\hline 33) Transportation Equipment & 23,712 & 20,474 & 43,298 \\
\hline 34) Miscellaneous Manufacturing & 31,739 & 27,406 & 57,955 \\
\hline 35) Construction of Buildings & 14,846 & 12,819 & 27,110 \\
\hline 36) Public and Other Construction & 52,494 & 45,327 & 95,856 \\
\hline
\end{tabular}




\section{Continued}

\begin{tabular}{lccc}
\hline 37) Electricity & 236,974 & 204,619 & 432,715 \\
38) Natural Gas & 2811 & 2426 & 5133 \\
39) Water, Sewage and Other Systems & 7052 & 6089 & 12,878 \\
40) Transportation and Warehousing & 184,279 & 159,119 & 336,494 \\
41) Information & 74,817 & 64,602 & 136,616 \\
42) Wholesale and Retail Trade & 716,579 & 618,743 & $1,308,475$ \\
43) Finance and Insurance & 961,066 & 829,850 & $1,754,910$ \\
44) Real Estate and Rental & 69,339 & 59,872 & 126,614 \\
45) Accommodation and Food Services & 23,683 & 20,448 & 43,244 \\
46) Other Industrial and Commercial Services & 462,430 & 399,294 & 844,399 \\
47) Public Administration & 8066 & 7565 & 16,655 \\
48) Educational and Health Care Services & 27,129 & 23,425 & 49,538 \\
49) Arts, Entertainment, and Recreation & 27,721 & 23,936 & 50,619 \\
50) Other Services & 168,113 & 144,499 & 304,853 \\
Total & $28,233,588$ & $24,378,738$ & $51,554,430$ \\
\hline
\end{tabular}

subsidies is about $1.12(=51.6 / 46.0)$, which is the only energy crop with benefit-cost ration greater than 1.0. This implies that sunflower production will be the most economic feasible choice among three energy crops when we take general economic impacts into account.

The general equilibrium economic impacts of energy crop production on the agriculture related sectors are summarized in Table 7. In the case of sunflower production, the total employment and average monthly wage rates in the Agricultural Sector will increase by $6.7 \%$ and $71.7 \%$, respectively. This indicates that sunflower production will have significant positive economic impacts on the employment and income of farmers in Tainan County.

\section{Concluding Remarks}

In this study, we develop an integrated assessment model to simulate the land use changes and economic impacts of energy crop policy in Taiwan. Our main findings can be summarized as follows: 1) There is lack of economic incentives for farmers to produce energy crops using set-aside croplands without government subsidies. The required subsidies for energy crops production will be 50\% to $120 \%$ higher than the original subsidies for set-aside croplands. Among three energy crops, sunflower has the lowest production costs and highest potential biodiesel output. 2) There is very little economic incentive for farmers to switch to energy crop production from existing crop production even with government subsidies. Therefore, the impacts on the supply and demand of existing agricultural crops are very minor. 3) Based on the geographic distribution of cropland land and soil grades, West Tainan County accounts for more than 
Table 7. Economic impacts of sunflower production on the agricultural sectors in Tainan county.

\begin{tabular}{lccccc}
\hline & $\begin{array}{c}\text { Initial } \\
\text { Employment } \\
\text { (person) }\end{array}$ & $\begin{array}{c}\text { Employment } \\
\text { Increase } \\
\text { (person) }\end{array}$ & $\begin{array}{c}\text { Total } \\
\text { Employment } \\
\text { (person) }\end{array}$ & $\begin{array}{c}\text { Monthly } \\
\text { Income } \\
\text { Increase } \\
\text { (NT\$) }\end{array}$ & $\begin{array}{c}\text { Average } \\
\text { Monthly } \\
\text { Income } \\
\text { (NT\$) }\end{array}$ \\
\hline 1) Rice & 72,335 & 2222 & 74,557 & 11,235 & 22,056 \\
2) Miscellaneous Crops & 7566 & 1482 & 9048 & 15,403 & 26,224 \\
3) Sugarcane & 603 & 113 & 716.3 & 6623 & 17,444 \\
4) All Other Grains & 7120 & 198 & 7318 & 4287 & 15,108 \\
5) Fruit and Tree Nut & 39,069 & 2440 & 41,509 & 4431 & 15,252 \\
6) Vegetable and Melon & 24,834 & 1488 & 26,322 & 6865 & 17,686 \\
7) Greenhouse and Nursery & 2751 & 1673 & 4424 & 3958 & 14,779 \\
$\begin{array}{l}\text { 8) Support Activities for } \\
\text { Crop Production }\end{array}$ & 1358 & 699.6 & 2058 & 4338 & 15,159 \\
Total & 155,636 & 10,316 & 165,952 & 7143 & 17,964 \\
\hline
\end{tabular}

two-third of total energy crop output in Tainan County. Among four soil grades, more than half of the total energy crop output comes from Grade II soil, which is mostly located in the West Tainan County. This implies that energy crop mills and refining plants should be located in the West Tainan County to minimize the transportation costs. 4) The results from general equilibrium modeling show that the Miscellaneous Crops sector will incur the largest increase in output due to energy crop production. It accounts for more than $50 \%$ of total output increase in Tainan County. In the case of sunflower production, the ratio of total output increase to total government subsidies is about 1.12, which is the only energy crop with benefit-cost ration greater than 1.0. This implies that sunflower is the most economical feasible choice among three energy crops. 5) In the case of sunflower production, the total employment and average monthly wage rates in the Agricultural Sector will increase by $6.7 \%$ and $71.7 \%$, respectively. This indicates that sunflower production will have significant positive economic impacts on the employment and income of farmers in Tainan County.

Based on our modeling approach and simulation results, the policy implications are expected to be multifaceted, including 1) provide a tool for developing agriculture land-use outlook for the decision-maker; 2) estimate trends in $\mathrm{CO}_{2}$ emission reduction and changes in land use and productivity; 3) assess the impacts of energy crop production and afforestation plantation on various economic sectors, especially on agriculture and farmer income.

\section{Conflicts of Interest}

The authors declare no conflicts of interest regarding the publication of this paper. 


\section{References}

[1] Intergovernmental Panel on Climate Change (IPCC) (1996) Climate Change 1995: Economic and Social Dimensions of Climate Change-Contribution of Working Group III to the Second Assessment Report of the Intergovernmental Panel on Climate Change. Cambridge University Press, Cambridge.

[2] Intergovernmental Panel on Climate Change (IPCC) (2001) Climate Change 2001: Mitigation-Contribution of Working Group III to the Third Assessment Report of the Intergovernmental Panel on Climate Change. Cambridge University Press, Cambridge.

[3] Intergovernmental Panel on Climate Change (IPCC) (2007) Climate Change 2007: Mitigation of Climate Change-Contribution of Working Group III to the Third Assessment Report of the Intergovernmental Panel on Climate Change. Cambridge University Press, Cambridge.

[4] Sands, R.D. and Leimbach, M. (2003) Modeling Agriculture and Land Use in Integrated Assessment Framework. Climatic Change, 56, 185-210. https://doi.org/10.1023/A:1021344614845

[5] Richards, K. and Stokes, C. (2004) A Review of Forest Carbon Sequestration Cost Studies: A Dozen Years of Research. Climatic Change, 63, 1-48. https://doi.org/10.1023/B:CLIM.0000018503.10080.89

[6] Sohngen, B. and Brown, S. (2006) The Influence of Conversion of Forest Types on Carbon Sequestration and Other Ecosystem Services in the South Central United States. Ecological Economics, 57, 598-708. https://doi.org/10.1016/j.ecolecon.2005.06.001

[7] van der Werf, E. and Perterson, S. (2007) Modeling Linkages between Climate Policy and Land Use: An Overview. Fondazione Eni Enrico Mattei Working Paper No. 56. https://doi.org/10.2139/ssrn.989968

[8] Golub, A., Hertel, T.W. and Sohngen, B. (2008) Land Use Modeling in Recursively-Dynamic GTAP Framework. GTAP Working Paper No. 48.

[9] Walsh, M.E., Delta Torre Ugarte, D.G., Shapouri, H. and Slinsky, S.P. (2003) Bioenergy Production in the United States: Potential Quantities, Land Use Changes, and Economic Impacts on the Agriculture Sector. Environmental and Resource Economics, 24, 313-333. https://doi.org/10.1023/A:1023625519092

[10] Yamamoto, H., Matsumura, Y. and Sawayama, S. (2005) Evaluation of Supply Potential of Energy Crops in Japan Considering Cases of Improvement of Crop Productivity. Biomass and Bioenergy, 29, 355-359. https://doi.org/10.1016/j.biombioe.2004.06.019

[11] Ignaciuk, A. and Dellink, R.B. (2006) Biomass and Multi-Product Crops for Agricultural and Energy Production-An AGE Analysis. Energy Economics, 28, 308-325. https://doi.org/10.1016/j.eneco.2006.01.006

[12] McDonald, S., Robinson, S. and Thierfelder, K. (2006) Impact of Switching Production to Bioenergy Crops: the Switchgrass Example. Energy Economics, 28, 243-265. https://doi.org/10.1016/j.eneco.2005.11.001

[13] Gurgel, A., Reilly, J.M. and Paltsev, S. (2007) Potential Land Use Implications of a Global Biofuels Industry. Journal of Agricultural \& Food Industrial Organization, 5 , 1-34. https://doi.org/10.2202/1542-0485.1202

[14] Raneses, A., Hanson, K. and Shapouri, H. (1998) Economic Impacts from Shifting Cropland Use from Food to Fuel. Biomass and Bioenergy, 15, 417-422.

https://doi.org/10.1016/S0961-9534(98)00048-8 
[15] McCarl, B.A. and Schneider, U.A. (2001) Greenhouse Gas Mitigation in U.S. Agriculture and Forestry. Science, 294, 2481-2482.

https://doi.org/10.1126/science.1064193

[16] Azar, C. (2005) Emerging Scarcities-Bioenergy-Food Competition in a Carbon Constrained World. Resource for the Future Inc. John Hopkins University Press, Baltimore.

[17] Berndes, G., Hoogwijk, M. and van den Broek, R. (2003) The Contribution of Biomass in the Future Global Energy Supply: A Review of 17 Studies. Biomass and Bioenergy, 25, 1-28. https://doi.org/10.1016/S0961-9534(02)00185-X

[18] Breuss, F. and Steininger, K. (1998) Biomass Energy Use to Reduce Climate Change: A General Equilibrium Analysis for Austria. Journal of Policy Modeling, 20, 513-535. https://doi.org/10.1016/S0161-8938(97)00073-2

[19] Kumbaroglu, G.S. (2003) Environmental Taxation and Economic Effects: A Computable General Equilibrium Analysis for Turkey. Journal of Policy Modeling, 25, 795-810. https://doi.org/10.1016/S0161-8938(03)00076-0

[20] McFarland, J.R., Reilly, J.M. and Herzog, H.J. (2004) Representation Energy Technologies in Top-Down Economic Models Using Bottom-Up Information. Energy Economics, 26, 685-707. https://doi.org/10.1016/j.eneco.2004.04.026 